20,1

60 Revised 31 March 2021 14 August 2021

Accepted 14 August 2021
INMR

Received 10 December 2020

\section{Technological and non-technological trends in fashion eco-innovations}

\author{
Maria Laura Ferranty Mac Lennan \\ Business Department, Ibirapuera University, Sao Paulo, Brazil and \\ Business Department, Centro Universitario da FEI, Sao Bernardo do Campo, Brazil \\ Eliane Fernandes Tiago \\ Business Department, Universidade Ibirapuera, Sao Paulo, Brazil, and \\ Cristina Espinheira Costa Pereira \\ Business Department, Ibirapuera University, Sao Paulo, Brazil
}

\begin{abstract}
Purpose - The fashion industry is diverse and demands a high amount of resources and labor for its operation. It has powerful tools that can positively impact the environment and society as a whole. In this sense, it becomes necessary for fashion to adopt sustainable strategies quickly. One way would be the adoption of ecoinnovations by companies in the sector. The objective of this research is to identify the main eco-innovation initiatives carried out by companies in the fashion sector and to verify what the trend is in the sector in relation to the types of eco-innovation, whether technological or non-technological in nature.

Design/methodology/approach - To meet the objective, the sector's sustainability reports are analyzed based on the Global Reporting Initiative (GRI) initiative. The method used to treat the data is content analysis. The authors chose to use the GRI-G4 and GRI-Standards versions of the GRI structure, as they include topics relevant to its stakeholders. The analysis based on these criteria considers 18 reports prepared by four companies (Cia Hering, Grupo Malwee, Dudalina and Lojas Renner).

Findings - From the data analysis, it was noticed that eco-innovations of technological trends prevail in Brazilian fashion, in the first place, those of process $(24.56 \%)$, followed by eco-innovations of product $(10.53 \%)$. The pressure exerted by internal or external stakeholders will be fueled by the current scenario of sustainable development, positively influencing the adoption of eco-innovation. This characteristic can be attributed to the fashion sector, since technological eco-innovations overlap with non-technological ones in all the years that make up the analysis.

Research limitations/implications - As limitations of this research, it is worth mentioning the availability of GRIs in the fashion sector. Even considering it a step forward, noting that larger companies support the adoption of these reports, it is important to highlight that only four companies make up the available database (Cia Hering, Lojas Renner, Dudalina and Malwee). From the adoption of the dissemination of sustainability reports by other organizations, the base could be expanded.

Practical implications - From this study, practical questions emerge that can contribute to managers and companies in the Brazilian fashion sector. Initially, the focus on eco-innovations is predominantly related to the technological component, with an emphasis on process eco-innovations. In this sense, business actions seek to resolve the accusations normally attributed to the sector, such as the adoption of unsustainable practices. For example, in cotton production, firms use large amounts of pesticides and water, despite the sector being accused of not taking proper responsibility regarding sustainability related issues.

Social implications - Investment in eco-innovations indicates a positive attitude and change resulting from pressure and the need to return the market to society's demands for more sustainable production technologies with less environmental impact.
\end{abstract}

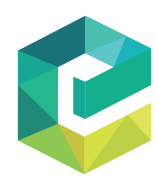

Innovation \& Management Review Vol. 20 No. 1,2023 pp. $60-75$

Emerald Publishing Limited $2515-8961$

DOI 10.1108/INMR-12-2020-0177

(c) Maria Laura Ferranty Mac Lennan, Eliane Fernandes Tiago and Cristina Espinheira Costa Pereira. Published in Innovation \& Management Review. Published by Emerald Publishing Limited. This article is published under the Creative Commons Attribution (CC BY 4.0) licence. Anyone may reproduce, distribute, translate and create derivative works of this article (for both commercial and non-commercial purposes), subject to full attribution to the original publication and authors. The full terms of this licence maybe seen at http://creativecommons.org/licences/by/4.0/legalcode. 
Originality/value - The originality of the study lies in the systematization of a GRI analysis model applied to measure eco-innovations in fashion. Through the applied methodology, it is possible to emphasize that ecoinnovations of technological trend prevail in the industry, first in processes and then in product development.

Keywords Green innovation, GRI fashion Industry, Technological trends

Paper type Research paper

\section{Introduction}

Discussions about innovation have been shaping business performance everywhere. One of the characteristics that influence business innovation most is the particularities of its industrial activity (Oliva et al., 2019). The fashion industry has been challenged to innovate from an environmental perspective, as it holds second place among the most polluting ones (Ellen MacArthur Foundation, 2017) and hence has been widely criticized for generating a high environmental impact. Poor environmental performance in raw materials, as in cotton production - which involves significant amounts of pesticides and water - makes it one of the most polluting crops in the world. Another criticism also comes from the generation of high social impacts. Thus, fashion may lack the environmental resilience found in sustainability because while the prospects for increasing productivity are uncertain, there is the certainty of increasing global challenges in the commercial sphere. In this sense, sustainability in fashion cannot be relegated to a secondary role. It becomes necessary to integrate it into the companies' corporate strategy (McKinsey Global Fashion Index, 2019) and adopt these sustainable strategies fast (Choi \& Han, 2019; Grose, 2019).

One way to make this transformation feasible in the fashion industry is to adopt eco-innovations. Eco-innovation (or sustainable innovation) deals with the production, assimilation or exploitation of a product, production process, service, management or business. This transformation reduces environmental risk, pollution and other negative societal impacts (Bossle, Dutra de Barcellos, Vieira, \& Sauvée, 2016; Kemp \& Pearson, 2007).

This research aims to identify the dimensions of eco-innovation carried out by fashion companies in Brazil and verify the predominant trend of the types of eco-innovation: whether they are technological or non-technological. Regarding the core of eco-innovation, technological relates to product or process innovations (Tumelero, Sbragia, \& Evans, 2019). These situations share aspects of the product's life cycle and go beyond the product's useful life, including aspects connected to reuse and recycling. Non-technological innovations refer to marketing and organizational types (Horbach, Oltra, \& Belin, 2013). We analyzed four industry's sustainability reports based on the Global Reporting Initiative (GRI) to achieve the goal of this study. Data analysis has been structured with the use of research propositions, elaborated from the literature review.

Innovation has reshaped organizations and serves as a response to global competition in the face of challenges in sustaining competitive advantage (Weerawardena \& Mavondo, 2011). Such initiatives can support actions in the industry and encourage the development of eco-innovation as a differentiating element in Brazilian fashion. This study compares the dimensions of eco-innovation proposed in the literature by García-Granero, Piedra-Muñoz, and Galdeano-Gómez (2018) to the data observed in the GRI reports of the Brazilian fashion industry. This crossover serves both to validate the dimensions proposed in the literature and present insights and suggestions for improvement for companies. These advances can occur both in the sustainability reporting process and in the formulation of environmental innovation strategies.

This study is organized as follows: first, the theoretical framework addresses the concepts of innovation and eco-innovation and the types of innovation in general and fashion in particular. In this section, we also develop the research proposals. Next, the methodology explains the research procedures adopted in data collection and analysis. Then, in
Fashion ecoinnovations 
INMR

20,1

62

Data analysis, we show the results, and the analysis is carried out. Finally, the concluding section and final recommendations complete the study.

\section{Theoretical framework}

The theoretical framework is initially organized by exposing the concepts of innovation, eco-innovation and their types. The text continues with the presentation of the dimensions applied in empirical research in the section entitled Eco-innovation in fashion. Finally, we build the theoretical model of analysis and formulate research proposals.

\subsection{Types of innovation and eco-innovation}

Innovation can be defined as the process that seeks to practically develop the use of an invention (Tidd \& Hull, 2006). Schumpeter (1942) was one of the first to distinguish invention, which is the creation of new products and processes, or the ideas that support them, from innovation, which encompasses the realization of new ideas into marketable products and processes. The business opportunities that arise from innovation lead to changes in consumer preferences, which is mainly due to what Schumpeter (1942) called creative destruction, that is, innovation destroys old consumption habits and from there create them anew. Thus, innovations have changed how we live, learn and communicate (Doran \& Ryan, 2016).

The Oslo Manual classifies innovations into four types: products, processes, business models or marketing (OECD, 2005). New technologies are introduced to the market by means of product innovation or the combination of existing technologies (Utterback \& Abernathy, 1975). In process innovation, there are new production flows, applications of labor and equipment, production specifications and materials in the production process. Marketing innovation considers the adaptations made in the company's marketing strategy, in which the application of new marketing methods is necessary. The innovation process involves significant improvements in product design, packaging, pricing, distribution, promotion and new means of distribution and sales channels (OECD, 2005; Tidd \& Hull, 2006). Finally, organizational innovation relates to new business models (Chesbrough, 2010) as they change the organizational paradigm by adopting new mental models that reorganize their work model (Teece, 2010).

Kemp and Pearson (2007) explain that some types of organizational innovation can contribute to the achievement of environmental goals, such as the implementation of training programs, green product design programs, learning structure and transformation programs for more environmentally friendly plants and processes through research and development (R\&D). Table 1 shows the definition of each type of innovation and its characteristics.

Eco-innovation is considered a direction adopted by companies encouraged by the government or demanded by society to contribute to sustainable development (Triguero, Moreno-Mondéjar, \& Davia, 2015). By integrating environmental innovation into its strategy, a company can increase sales and competitive advantage, attract new markets, improve its financial performance, enrich its corporate impact, differentiate its product(s) and improve the environment (Doran \& Ryan, 2016; Dangelico \& Pontrandolfo, 2015; Porter \& Van der Linde, 1995; among others). The company is characterized according to its objective (focus on products, processes, marketing methods, institutions and organizations) or its mechanisms, whether modification, redesign, alternative rearrangement, recreation or environmental impacts. This means that corporations can design and analyze their eco-innovative initiatives and strategies relating to specific areas, goals, type of progress achieved and impacts resulting from their actions (García-Granero et al., 2018).

The development of eco-innovations occurs at the company's technological frontier since the risks and uncertainties arising from innovation are enhanced when there is little 
Type of

innovation

Definition

Product

innovation

Process

innovation

Marketing

innovation

Organizational innovation
It is the introduction of a new or significantly improved good or service in terms of its characteristics or intended uses. It can add new knowledge or be based on new uses or combinations of existing knowledge or technologies

It is the implementation of a new or significantly improved production method

It is the implementation of a new marketing system with changes in product design or packaging, product positioning, promotional strategy or pricing

It is the implementation of a new organizational method in the company's business practices, reorganizing the way of doing business or even external relations
Innovation characteristics

May include significant improvements in technical specifications, components, and materials, embedded software, ease of use and other functional capabilities

It aims to reduce production or distribution costs, improve quality or even produce or distribute new or improved processes

It aims to meet the needs of consumers, open new markets, or reposition a company's product, aiming at increasing sales. It may include new sales channels and substantial design changes that do not alter their functional characteristics or product packaging

It aims to improve a company's performance by reducing costs, whether administrative or transaction, stimulating satisfaction in the workplace, leading to improved productivity, fostering new relationships and technologies
Fashion ecoinnovations

Table 1.

Types of innovation, definitions and characteristics

experience in implementing sustainable innovations (De Marchi, 2012). The different types of innovations (products, processes, marketing and organizational) permeate technology, providing a broader dialogue between scientific research, technological innovation and social development. Furthermore, technology favors the achievement of immense scientific progress and overall economic growth; these goals aim at ethical and social achievement, providing a sustainable transformation (Chen, Yin, \& Mei, 2018). The Oslo Manual (OECD, 2005) classifies product and process innovations as technological innovations. Marketing and organizational innovations are referred to there as non-technological. The technological types of eco-innovations (products and processes) are related to the development of new technologies, processes and methodologies (Chen et al., 2018). Some examples are the use of materials with less environmental impact, sustainable energy sources and the use of recyclable materials (García-Granero et al., 2018).

Kemp and Pearson (2007) suggested that eco-innovation can be explained as the manufacture, assimilation or exploitation of a product, production process, service, management or business method that is new to the company and that results, throughout its cycle of life, in a reduction of environmental risk, pollution and other negative impacts of resource use (including energy use), compared to relevant options. Furthermore, eco-innovation requires the development of more efficient and effective products from the point of view of environmental resources (Hsu, Tan, \& Zailani, 2016), since the concept focuses on creating new products or improving existing ones, in addition to promoting environmental advances in logistical processes. Thus, eco-innovation provides significant and visible progress toward sustainable development through reduced use of environmental resources or more efficient and responsible use of natural resources, including energy and water (Hroncova, JanaJadudová, Hronec, \& Rolíková, 2017). Briefly, eco-innovation can be 
INMR

20,1

\section{4}

defined as innovation for sustainability (Arranz, Arroyabe, Molina-García, \& de Arroyabe, 2019).

2.1.1 Dimensions of eco-innovation in fashion. The fashion industry is very much interconnected with other industries, such as agriculture, chemistry, engineering, design and marketing. García-Granero et al. (2018) propose dimensions for implementing eco-innovation that can be applied to the fashion industry. They are described in Table 2:

The purpose of the dimensions indicated in Table 2 is to translate in a practical way how each of the different types of eco-innovation takes place in the fashion industry. This information is necessary to measure the level of eco-innovation accurately and is helpful in companies' performance evaluations. A sustainable apparel company can reduce pollution, consume fewer resources, maintain a safe workplace and promote quality non-toxic and durable products for the consumer. Different strategies can be considered depending on the level or degree of innovation. Four levels of innovation can be defined: (1) product level improvement, (2) product redesign, (3) innovation function and (4) system innovation (Kozlowski, Searcy, \& Bardecki, 2015). In this sense, eco-innovation can be linked to technological development since the main determinants of its implementation depend on the technology.

Brazilian fashion has been challenged to develop technological eco-innovations. However, there is a consensus that environmental issues do not represent the core competencies of most companies (Horbach et al., 2013), especially in the fashion industry. As this is an emerging market, the Brazilian institutional environment has less investment capacity in technology innovations, given that they demand financial investments and resources such as R\&D know-how. Furthermore, companies from emerging markets have less access to cutting-edge technologies, as they occur in an environment with developed innovation systems (Figueiredo, 2009). In the fashion industry, the development of technologies occurs through research and innovations in new fabrics, raw materials and design, elements that

\begin{tabular}{ll}
\hline Types of eco-innovation & Dimensions of eco-innovation performance \\
\hline Product eco-innovation & - Use of new materials with less environmental impact \\
& - Use of recycled raw materials \\
& - Reduction in the use of raw materials and the number of components in the \\
& product \\
& - Elimination of the use of polluting materials \\
& - Increased product life \\
& - Production of recyclable products \\
& - Reduction of chemical waste \\
& - Decrease in the use of water and energy \\
& - Reuse of components \\
& - Usage of eco-sustainable technologies \\
Process eco-innovation & - Use of energy from renewable sources \\
& - Use of recyclable or reusable packaging \\
& - Green packaging design \\
& - Quality/environmental certifications \\
Marketing eco-innovation & - Green human resource management \\
& - Pollution prevention initiatives in factories \\
& - Environmental audits \\
Organizational & - Eco-friendly objectives \\
eco-innovation & - Investments in R\&D \\
& - Cooperation with stakeholders \\
& - New markets \\
& - Use of novel logistic systems \\
& Source(s): Adapted from García-Granero et al. (2018) \\
&
\end{tabular}

Table 2.

Dimensions of ecoinnovation performance

\author{
Source(s): Adapted from García-Granero et al. (2018)
}


add value to the final product (MacLennan, Suter, \& Spers, 2017) and can be related to eco-innovations. Thus, the following research proposition is presented:

P1. Eco-innovations in Brazilian fashion point to a greater emphasis on product and process innovations, i.e. technological trends.

Eco-innovation development initiatives are aligned with the principles of sustainable development. They consider adopting new practices and procedures in the organization that minimize or eliminate environmental risks, pollution and other negative impacts of organizational practice (Kemp \& Pearson, 2007). On the other hand, non-technological innovation relates to organizational and marketing innovations, such as cooperation between customers, suppliers and other members of the fashion production chain, the implementation of environmental audits and the search for environmental certifications (García-Granero et al., 2018; Borini, MacLennan, Pereira, Pavan, \& Hourneaux, 2018). Therefore, eco-innovations can be defined as a set of technologies, techniques and procedures, or even management guidelines and procedures (Shrivastava, 1995), in the case of marketing and organizational eco-innovations.

In the case of Brazilian fashion, based on previous studies, the emphasis is on fashion design initiatives, for example, in the beachwear industry (Kury, da Rocha, \& da Silva, 2019). The adoption of Brazilianness (such as colors, vibrancy and joy associated with the image of Brazil) adds differentiating characteristics to Brazilian fashion, such as designs associated with elements of national culture, quality of support and customer service (Sutter, MacLennan, Polo, \& Strehlau, 2016). Therefore, companies seek to differentiate Brazilian fashion through strategies that involve valuing brands and investing in a differentiated offer (Silva, Vicente, \& Galina, 2013) and the development of digital sales channels (De Morais, Hoeckesfeld, Sarquis, \& Mussi, 2019). Such actions would encourage fashion to invest in marketing and organizational eco-innovations. In this sense, the following research proposition comes up:

P2. Eco-innovations in Brazilian fashion point to a greater emphasis on marketing and organizational innovations, i.e. non-technological trends.

Figure 1 brings the two propositions that guide this research. If confirmed, the first proposition (P1) will indicate the trend and the predominance of technological eco-innovations in fashion in Brazil. On the other hand, if the second proposition (P2) is confirmed, a trend toward non-technological eco-innovations in this industry will be observed. This analysis allows us to point out convergences on what is being done and what still needs to be done in the industry concerning eco-innovations.

\section{Methodological procedures}

To achieve the proposed objective, qualitative and exploratory research was carried out. The object of the study, namely, eco-innovation trends and the Brazilian fashion industry, was chosen as an empirical field. The applied research methodology is the so-called documentary one that seeks to capture a phenomenon from the perspective contained in the documents. Document analysis in the qualitative approach consists of an extensive examination of original materials (Kripka, Scheller, \& Bonotto, 2015).

The content analysis (CA) technique is generally used in documentary research (Sá-Silva, Almeida, \& Gindani, 2009). According to Berelson (1952), CA is an objective, systematic and numerical research technique, using counting and frequency techniques, in which the description of the content is manifested through communication. The researcher looks for patterns that fit into specific categories that, in this work, were previously defined based on the literature. The aim of $\mathrm{CA}$ is the inference of knowledge related to the conditions of

Fashion ecoinnovations 
INMR

20,1

\section{6}

Figure 1.

Conceptual model

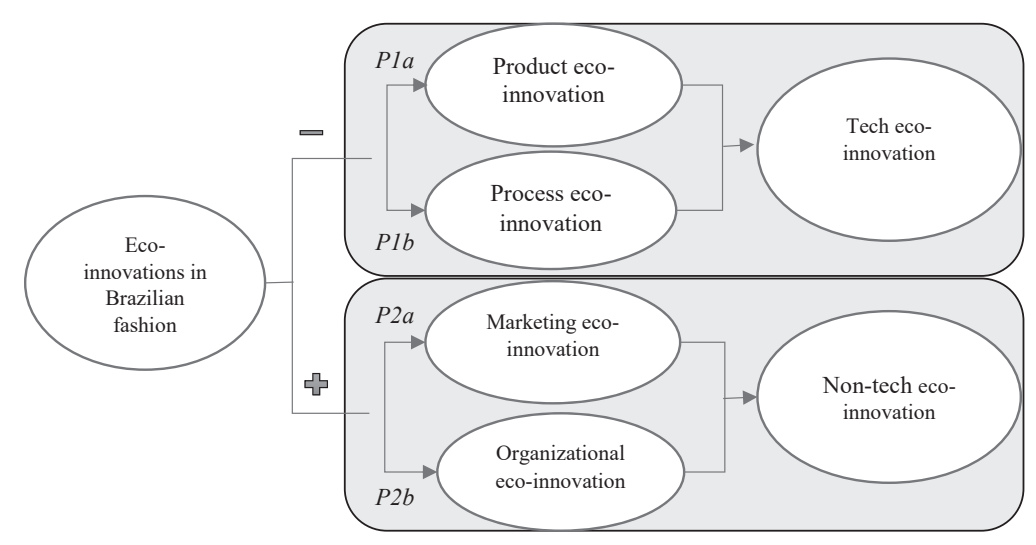

production and reception of messages, an inference that uses indicators, either quantitative or not (Bardin, 2016).

\subsection{Data}

For the research corpus, we used secondary data consisting of sustainability reports published in the GRI. It includes reports from Brazilian fashion companies to ensure homogeneity of materials. Each report corresponds to a company, which are the units of analysis. Reports published from 2015 to 2019 were collected - they are easily accessible at www.globalreporting.org. The time frame (from 2015) was due to the availability of data, once before 2015 there are sparse reports, and there is no consistency in their publication.

There are many examples in the literature of studies carried out using data collected in GRI reports: Environmental investigative survey of management practices and performance of companies in Sweden, China and India (Chen, Tang, \& Feldmann, 2015); sustainability in Swedish Companies (Hedberg \& Von Malmborg, 2003); cross-sectional analysis of the performance of $\mathrm{CO}_{2}$ emissions between GRI reporting and non-reporting companies (Belkhir \& Elmeligi, 2018); determinants of GRI-based sustainability reports: evidence of an emerging economy (Orazalin \& Mahmood, 2020). All these documents are considered a suitable and sufficient source for carrying out documentary research.

We chose to use the GRI-G4 and GRI-standards versions of the GRI structure, as they include topics relevant to its stakeholders, civil society and employees without being dispersed in intermediate reports. This "materiality" makes the report more reliable and allows organizations to provide more detailed information about sustainability issues (Mascena, Fischmann, \& Boaventura, 2018). The corporations and reports accessed are detailed in Table 3:

The analysis considers all 17 available reports prepared by four companies in the fashion industry (Cia Hering, Grupo Malwee, Dudalina and Lojas Renner). The reports have an average of 80 pages each and were thoroughly analyzed. Dudalina's missing reports for the period 2017 to 2019 are due to the fact that in 2014 it became controlled by Restoque Comércio e Confecções de Roupas SA; after the merger, the company continued to publish reports in the GRI in 2015 and 2016. However, from 2017 onwards, it has only made financial statements available on the parent company's website.

\subsection{Stages of data analysis and presentation}

Figure 2 shows the steps of the data analysis procedure. After collecting the reports, the NVivo software, version 12 Plus, was used. This software offers the function of bringing the researcher closer to the material, facilitating its manipulation and refinement. Importantly, 
like any other qualitative analysis software, NVivo helps the researchers "manage, explore and find patterns in their data, but it does not replace their analytical knowledge" (NVivo11, 2016, p. 7).

When creating the research project in Nvivo, we also inserted the types of eco-innovation defined by the Oslo Manual: product, process, organization and marketing (OECD, 2005). These types became the codes (also called nodes) used in the second step. Coding is the process of assigning codes to text fragments to allow future associations of these fragments under the same code and the organization of models of conceptual relationships between them (Miles \& Huberman, 1994).

With the creation of the codes, the text manipulation steps are next. The second and third steps consist of systematic and analytical reading, citation selection (excerpts), coding and aggregation of raw data (Miles \& Huberman, 1994), here called Citation Reports 1 and 2. The fourth step contributes to the rigor and credibility of the analyses, so it is advisable that more than one person carry out the process to minimize the researcher's bias.

The last stage of the analysis consists of presenting evidence taken from the reports that support the CA. These examples, obtained from the documents cited in Table 3 , indicate how companies act concerning eco-innovations. The more citations assigned to certain subcodes, the more evidence that actions are taken within that category; that is, the software transforms the citation in the report into an area described quantitatively with the assigned percentage. Thus, the percentage calculated by Nvivo corresponds to the representativeness of the area marked in the report. If the percentage is zero, the dimension was not present in the company's GRI report for that year.

In this case, the CA acquires a quantitative character, and the metrics adopted are: (1) the number of citations (per code and company/code) in order to identify if they are shares of a single company; (2) per subcode and company/subcode; and (3) text coverage for each code and subcode. The latter is given by Nvivo and represents the percentage of report text that

\begin{tabular}{|c|c|c|c|c|c|c|}
\hline Company & $\begin{array}{l}\text { Year } \\
2015\end{array}$ & 2016 & 2017 & 2018 & 2019 & Total \\
\hline Cia. Hering & GRI & GRI & GRI & GRI & GRI & 5 \\
\hline Dudalina & GRI & GRI & $(*)$ & $(*)$ & $(*)$ & 2 \\
\hline Grupo Malwee & GRI & GRI & GRI & GRI & GRI & 5 \\
\hline Lojas Renner & GRI & GRI & GRI & GRI & GRI & 5 \\
\hline Total & 4 & 4 & 3 & 3 & 3 & 17 \\
\hline
\end{tabular}

Note(s): $(*)$ = Report not available
Fashion ecoinnovations
Table 3. Companies and reports

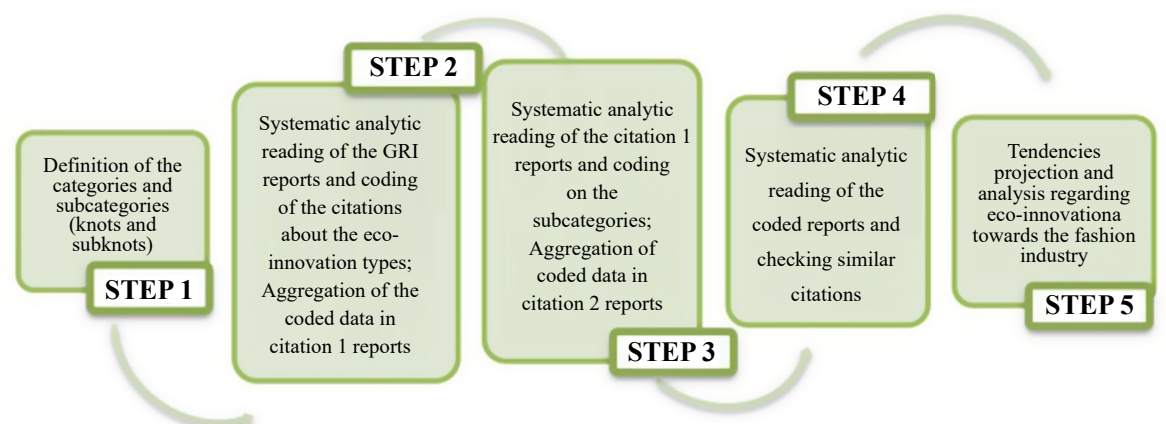

Figure 2. Analysis path 
INMR

20,1

\section{8}

Table 4.

Evolution of product eco-innovation dimensions from GRIs data

has been coded for a particular category (node) or subcategory (sub-node). This analysis is based on the premise that the more relevant the topic addressed, the greater its representativeness in the analyzed report, which allows us to verify the importance companies give to the types of eco-innovation and which dimensions they consider more relevant for good performance in the Brazilian fashion industry.

In this work, the dimensions proposed in the literature were used to identify the implementation of the four eco-innovations categories. Existing literature identifies categories of analysis, or nodes, previously shown in Table 2. The citations of excerpts from the reports will be used for illustration purposes only, including adding validity and reliability to the research (Miles \& Huberman, 1994). The trends in product and process eco-innovations are presented first, given their technological component (Tables 4 and 5), whereas the evolution of marketing and organizational eco-innovations is shown later (Tables 6 and 7).

\section{Analysis of results}

In the report analysis (Table 4), we can see eco-innovation dimensions that are more representative among those indicated by García-Granero et al. (2018), namely, (1) use of new materials with less environmental impact $(3.01 \%)$ and (2) production of recyclable products $(2.49 \%)$. On the other hand, the dimension with the lowest incidence is the elimination of the use of polluting materials $(0.68 \%)$. Table 4 shows the representativeness of each dimension from the analyzed data.

\begin{tabular}{|c|c|c|c|c|c|c|}
\hline$\%$ Coverage & 2015 & 2016 & 2017 & 2018 & 2019 & Total \\
\hline Use of new materials with less environmental impact & $0.90 \%$ & $0.00 \%$ & $0.00 \%$ & $0.46 \%$ & $0.00 \%$ & $1.36 \%$ \\
\hline Use of recycled raw materials & $0.00 \%$ & $0.00 \%$ & $0.00 \%$ & $0.32 \%$ & $0.36 \%$ & $0.68 \%$ \\
\hline $\begin{array}{l}\text { Reduction in the use of raw materials and number of } \\
\text { components in the product }\end{array}$ & $1.27 \%$ & $0.00 \%$ & $1.04 \%$ & $0.04 \%$ & $0.14 \%$ & $2.49 \%$ \\
\hline Elimination of the use of polluting materials & $0.00 \%$ & $0.00 \%$ & $0.07 \%$ & $0.00 \%$ & $1.73 \%$ & $1.80 \%$ \\
\hline Increased product life & $0.25 \%$ & $0.06 \%$ & $0.20 \%$ & $0.23 \%$ & $0.45 \%$ & $1.19 \%$ \\
\hline Production of recyclable products & $0.72 \%$ & $0.25 \%$ & $0.60 \%$ & $0.61 \%$ & $0.83 \%$ & $3.01 \%$ \\
\hline Total & $3.14 \%$ & $0.31 \%$ & $1.91 \%$ & $1.66 \%$ & $3.51 \%$ & \\
\hline
\end{tabular}

\begin{tabular}{lcccccr}
\hline \% Coverage & 2015 & 2016 & 2017 & 2018 & 2019 & Total \\
\hline Reduction of chemical waste & $0.52 \%$ & $0.89 \%$ & $1.31 \%$ & $0.48 \%$ & - & $3.20 \%$ \\
Decrease in the use of water and energy & $4.16 \%$ & $3.19 \%$ & $5.29 \%$ & $1.24 \%$ & $0.82 \%$ & $14.70 \%$ \\
Reuse of components & - & $0.30 \%$ & - & - & $0.19 \%$ & $0.49 \%$ \\
Use of eco-sustainable technologies & $0.26 \%$ & - & - & $1.40 \%$ & $3.26 \%$ & $4.92 \%$ \\
Use of energy from renewable sources & - & $0.36 \%$ & $0.01 \%$ & $0.53 \%$ & $0.35 \%$ & $1.25 \%$ \\
Total & $4.94 \%$ & $4.74 \%$ & $6.61 \%$ & $3.65 \%$ & $4.62 \%$ & \\
\hline
\end{tabular}

Table 5 .

Evolution of the ecoinnovation dimensions of processes from GRIs data

\begin{tabular}{lcccccr}
\hline$\%$ Coverage & 2015 & 2016 & 2017 & 2018 & 2019 & Total \\
\hline Use of recyclable or reusable packaging & $1.44 \%$ & $1.76 \%$ & $0.32 \%$ & $0.37 \%$ & $0.21 \%$ & $4.10 \%$ \\
Green packaging design & $0.09 \%$ & - & - & - & $0.07 \%$ & $0.16 \%$ \\
Quality/environmental certifications & $0.13 \%$ & $0.45 \%$ & - & $0.47 \%$ & $0.05 \%$ & $1.10 \%$ \\
Total & $1.66 \%$ & $2.21 \%$ & $0.32 \%$ & $0.84 \%$ & $0.33 \%$ & \\
\hline
\end{tabular}

Table 6.

Evolution of the marketing ecoinnovation dimension from GRIs data 
As to the use of new materials with less environmental impact, initiatives such as Malwee's use of biodegradable polyamide yarn (Rhodia's Amni ${ }^{\circledR}$ Soul Eco yarn) and recycled PET yarn can be highlighted (GRI Malwee report, 2015). It is also noteworthy the use of ecological biodegradable fiber made from wood cellulose from sustainable management forests (Liocel) by Lojas Renner (GRI Lojas Renner report, 2017, 2018, 2019). Dudalina also informs that it uses more than $90 \%$ of materials from renewable sources (GRI Dudalina report, 2016). In this sense, eco-innovations are closely related to applying new yarn and fabric technologies that impact both the production of the threads and their disposal, as some are biodegradable.

The assessment per company shows that the organization with the highest incidence of the use of new materials with less environmental impact is Lojas Renner (1.49\%). One action to be highlighted is the use of 3.2 tons of agroecological cotton produced by quilombola women supported by the Instituto Lojas Renner (GRI Lojas Renner report, 2019). In this dimension, Dudalina $(0.09 \%)$ is less representative.

Initiatives related to producing recyclable products often involve the production of jeans. Malwee and Lojas Renner recycle jeans to create new products. Lojas Renner, for example, through the brand "Youcom," launched in 2017, the hashtag \#YouRecycle (GRI Lojas Renner, report 2017) that consists of a capsule collection that featured five products (pants, jacket, dress, skirt and shorts) made of recycled textile material or PET. The products carry special tags, on seed paper, with information about better habits to minimize environmental impacts. Another notable initiative, now by Hering, was the launch of a limited edition of seven models made with sustainable fabric, combining recycling, reuse and reduction of environmental impacts, renewed in the following collections (GRI Cia. Hering report, 2017).

As a proposal to increase the product's useful life, we can mention the initiative of Hering in a partnership with Pantys (GRI Cia. Hering report, 2017), which is the launching of products that support the replacement of disposable pads with durable pads. This collaborative action supports the ideas of Diaz-Garcia, Gonzalez-Moreno, and Saez-Martinez (2015) concerning the relevance of networking for eco-innovation and the search for environmentally sustainable technological solutions.

When analyzing eco-innovations in fashion processes, the most representative dimension among those indicated by García-Granero et al. (2018) is the reduction in the use of water and energy $(14.7 \%)$, followed by the use of eco-sustainable technologies $(4.92 \%)$. The data regarding the representativeness of each dimension are presented in Table 5 .

The reduction in water and energy can be exemplified by initiatives in the production process such as Hering's, which promotes a water treatment system using reverse osmosis and rainwater capture (GRI Cia Hering report, 2018). Malwee informs that

The most recent innovation we have developed concerns the process of dyeing items in neon, a technique that requires a high volume of water to which, fortunately, the Malwee Group found an
Fashion ecoinnovations

\begin{tabular}{|c|c|c|c|c|c|c|c|}
\hline$\%$ Coverage & 2015 & 2016 & 2017 & 2018 & 2019 & Total & \\
\hline Green human resource management & $0.29 \%$ & $0.00 \%$ & $0.14 \%$ & $0.00 \%$ & $1.50 \%$ & $1.93 \%$ & \\
\hline Pollution prevention initiatives in factories & $0.19 \%$ & $0.00 \%$ & $0.00 \%$ & $0.00 \%$ & $0.00 \%$ & $0.19 \%$ & \\
\hline Environmental audits & $0.21 \%$ & $0.52 \%$ & $0.00 \%$ & $0.39 \%$ & $0.00 \%$ & $1.12 \%$ & \\
\hline Eco-friendly objectives & $0.85 \%$ & $0.00 \%$ & $0.36 \%$ & $0.00 \%$ & $0.07 \%$ & $1.28 \%$ & \\
\hline Investments in $\mathrm{R} \& \mathrm{D}$ & $0.00 \%$ & $0.00 \%$ & $0.00 \%$ & $0.00 \%$ & $0.15 \%$ & $0.15 \%$ & Table 7. \\
\hline Cooperation with stakeholders & $0.43 \%$ & $0.34 \%$ & $0.00 \%$ & $0.00 \%$ & $0.00 \%$ & $0.77 \%$ & Evolution of \\
\hline New markets & $0.00 \%$ & $0.00 \%$ & $0.30 \%$ & $0.00 \%$ & $0.00 \%$ & $0.30 \%$ & organizational eco- \\
\hline Use of novel logistic systems & $0.19 \%$ & $0.60 \%$ & $0.04 \%$ & $0.83 \%$ & $0.28 \%$ & $1.94 \%$ & innovation dimensions \\
\hline Total & $2.16 \%$ & $1.46 \%$ & $0.84 \%$ & $1.22 \%$ & $2.00 \%$ & & from GRIs data \\
\hline
\end{tabular}


INMR

20,1

alternative that maintains quality but saves up to $98 \%$ of water use. To achieve such an expressive reduction, we substituted the dyeing step in the production process by a process similar to printing (GRI Malwee report, 2018)

Lojas Renner, on the other hand, has been replacing light bulbs in stores with LED due to their energy efficiency, among other initiatives (GRI Lojas Renner report, 2019).

The analysis per company shows that Malwee is the one with the highest incidence of water use reduction initiatives $(6.87 \%)$. This is because Malwee carries out pioneering initiatives such as the use of PET mesh, shredded cotton and dyeing processes that save up to $98 \%$ of the water volume (GRI Malwee report, 2017). The company with the lowest incidence in this dimension is Dudalina with $0.26 \%$.

The initiatives about the use of eco-sustainable technologies occur not only within the company but also in partnerships with its suppliers. Lojas Renner, for example, led a project with six suppliers in the jeans and knitwear chain and achieved a reduction in the disposal of 388 tons of waste, and the launch of its first collection of recycled jeans, Re Jeans (GRI Lojas Renner report, 2018). Thus, with the improvements in fabric cutting processes, 47 tons of textile waste were no longer generated in 2018 by this company alone. This initiative allowed the waste previously sent to landfills to be returned to the organization as recycled fabric. Hering illustrates another initiative, implemented at the end of 2019, which seeks ecoefficiency for the production process. The project includes reusing the hot effluents that exit the dyeing processes as a heating source for the water that enters the same process through heat exchangers (GRI Cia Hering report, 2019). Such a change reduces the demand for other fuels needed to heat water. With investments of $\mathrm{BR} \$ 900,000$, their project will bring significant gains in energy savings in 2020. This dimension must be highlighted as a growing trend among process eco-innovations.

The item with the lowest representation in process eco-innovations is the reuse of components, with $0.49 \%$ of the initiatives. An example is the reuse and recycling of furniture and mannequins discarded in the renovations of Lojas Renner (GRI Lojas Renner report 2016). About 450 mannequins were sent for reuse, and more than $40 \%$ of the obsolete furniture discarded in renovations was recycled, thus significantly reducing the percentage of materials sent to landfills. The project also made it possible to reduce the cost per $\mathrm{kg}$ in the final disposal of these wastes, resulting in BR $\$ 90,000$ in savings (compared to 2015 values). Table 6 presents the representation in the GRIs reports of the dimensions of eco-innovations in marketing. It appears at a lower frequency than that of products and processes.

In marketing, eco-innovations, quality and environmental certifications stand out, with $4.1 \%$ coverage. These can be understood as a type of non-technological innovation (Borini et al., 2018; García-Granero et al., 2018), essential for consolidating the company's environmental image. Its importance is justified because an increasing number of companies are seeking these certifications to meet the demands of stakeholders. The example of Lojas Renner, in this matter, is noteworthy, as they obtained the certification of the Carbon Efficient Index $\left(\mathrm{ICO}_{2}\right)$ from B3 in 2014 (GRI Lojas Renner report, 2015), renewing it annually since then, given the demand for actions to minimize global warming.

The evaluation per company of trends in marketing eco-innovations in the quality and environmental certification dimension highlights Hering (2.31\%), for it has developed initiatives both in the company's technological structure and in better digital experiences with a multi-channel service to satisfy the customer (GRI Hering report, 2016). This experience highlights the importance of marketing innovations to an omnichannel strategy in Brazilian fashion retail (De Morais et al., 2019). This initiative also reduces the use of resources, as it minimizes the need for physical infrastructure and customer travel.

Another highlight in this dimension is the use of recyclable or reusable packaging (1.10\%), as all companies considered it to a greater or lesser extent; for example, Malwee, where 85\% 
of the consumption of bags used either in their own brand or in the multi-brands are made of oxo-biodegradable plastic (GRI Malwee report, 2018). In other words, the packaging contains an additive that makes it degrade in approximately 18 months if disposed of in an open-air environment, in contact with heat, UV rays and oxygen. The remaining $15 \%$ are bags made of FSC - Forest Stewardship Council-certified paper and recyclable plastics.

Table 7 shows the evolution of the representation of organizational eco-innovations in the GRIs according to the dimensions proposed by García-Granero et al. (2018).

As it happened with the marketing eco-innovations already discussed in the previous analysis, organizational eco-innovations show a stable trend over the years at a lower level than those of a technological nature (product and process eco-innovations). There is a clear trend toward using new logistic systems with $1.94 \%$ coverage, followed by the application of green human resources policies with $1.93 \%$. It is also noteworthy that the representation of organizational eco-innovations increased in 2019, compared to previous years. The dimension on the use of new logistic systems emerges as the most representative. Hering, for example, has adopted from 2015 distribution by regional hubs, optimizing routes and using its fleet more effectively, reducing fuel consumption and generating less environmental impact (GRI Hering report, 2015).

In terms of logistic systems, in addition to the distribution of goods, Lojas Renner's "EcoEstilo" Program stands out, a reverse logistics service offered to clothes and perfumery customers. The service in the perfume commerce existed since 2011, making it easier for customers to discard packages and bottles, even if they have not been purchased at Renner. The collected waste is disposed of in an environmentally correct way, avoiding environmental contamination. The same service has been offered since 2017 for clothes. In 2018, the service was expanded from 15 pilot stores to 50 stores, totaling 65 stores in 21 states. In two years, $249 \mathrm{~kg}$ of clothes were collected for recycling through shredding and reused by upcycling or donation. Thus, it is clear that companies strive to adopt new logistical systems, ensuring the intelligent supply of their stores and resellers (GRI Lojas Renner reports, 2017, 2018, 2019).

It is also noteworthy the dimension of green human resources $(1.93 \%)$, a good example being Lojas Renner, which has maintained the Renner University since 1995, a network of learning experiences that connect employees of Renner, YouCom, Camicado and Perform in the countries where they operate. The university has a modern learning platform that encourages networks of experiences and connections between employees to enhance the exchange of knowledge (GRI Lojas Renner report, 2017). Hering also has a corporate University (GRI Hering report, 2015).

Table 8 shows the consolidation of dimensions and their representation in the four types of eco-innovation in fashion. It organizes the data and research propositions and shows the development of eco-innovations in the analyzed GRI reports and their evolution trend. The year with the highest representation of eco-innovation actions is 2015, followed by 2019 .

Kemp and Pearson (2007) understand that eco-innovation can be scaled from traditional types of innovation; that is, it can occur at the product, production process and organizational management levels. The companies reports' data evidenced the analysis of the dimensions

\begin{tabular}{lrrrrrrr}
\hline \% Coverage & 2015 & 2016 & 2017 & 2018 & 2019 & Total & \\
\hline Eco-inovações de Produto (P1a) & $3.14 \%$ & $0.31 \%$ & $1.91 \%$ & $1.66 \%$ & $3.51 \%$ & $10.53 \%$ & Table 8. \\
Eco-inovações de Processo (P2) & $4.94 \%$ & $4.74 \%$ & $6.61 \%$ & $3.65 \%$ & $4.62 \%$ & $24.56 \%$ & Research propositions \\
Eco-inovações de Marketing (P3) & $1.66 \%$ & $2.21 \%$ & $0.32 \%$ & $0.84 \%$ & $0.33 \%$ & $5.36 \%$ & and eco-innovation \\
Eco-inovações Organizacionais (P4) & $2.16 \%$ & $1.46 \%$ & $0.84 \%$ & $1.22 \%$ & $2.00 \%$ & $7.68 \%$ & dimensions from \\
Total & $11.90 \%$ & $8.72 \%$ & $9.68 \%$ & $7.37 \%$ & $10.46 \%$ & the GRIs \\
\hline
\end{tabular}

Fashion ecoinnovations 
INMR

20,1

proposed by García-Granero et al. (2018). Regarding the research propositions, it is evident that P1 overlaps P2. That is, eco-innovations prevail in the technological trends of Brazilian fashion. In the first place, processes $(24.56 \%)$ followed by eco-innovations of products $(10.53 \%)$. Thus, technological trends in eco-innovation (process and product) prevail over eco-innovations of a non-technological nature based on the reports of the analyzed companies.

The market structure can be highlighted as a driver of innovations in fashion, predominantly in the development of process technology. Eco-innovation directs the scope for more sustainable development so that, in addition to the innovation trait, its results benefit the environment. Therefore, the pressure exerted by internal or external stakeholders will be fueled by the current scenario of sustainable development, positively influencing the adoption of eco-innovation (Triguero et al., 2015). This characteristic can be attributed to the fashion industry since technological eco-innovations overlap non-technological in all the years that make up our analysis.

\section{Conclusions and final recommendations}

As discussed in the Introduction, this research aimed to identify the main eco-innovation initiatives carried out by companies in the fashion industry in Brazil. Furthermore, the objective was to verify the industry's trend concerning the types of eco-innovation, whether technological or non-technological. The industry's sustainability reports have been analyzed based on the GRI to meet that objective.

The results indicate that product and process eco-innovations, so-called technological, predominate in the fashion industry, especially process innovations, driven by technological capabilities and market forces. In this sense, aspects related to reducing water and energy use and enhancing eco-sustainable technologies emerge as the main drivers of process eco-innovations in the fashion industry. Regarding product eco-innovations, the use of new materials with less environmental impact and the production of recyclable products stand out as industry trends; however, with less emphasis than process eco-innovations.

Based on the analysis, it is noticeable that marketing and organizational eco-innovations (non-technological) are less prevalent in the fashion industry. Among the marketing eco-innovations, we can highlight the adoption of quality and environmental certifications and the use of recyclable or reusable packaging. In the case of organizational eco-innovations, companies tend to direct actions towards using new logistical systems and adopting green human resources policies. Furthermore, our results corroborate previous research indicating design, modeling and use of colors as differentiating elements of Brazilian fashion (Sutter, Galleli, MacLennan, Polo, \& Correa, 2015; Sutter et al., 2016). The results also show the disconnection observed between the dimensions explained in theory and the actions actually taken by the companies.

An academic contribution of this study is the application in an empirical case of the dimensions of eco-innovation proposed by García-Granero et al. (2018). The authors indicated a gap in the literature, as the studies do not include a complete combination of the four types of eco-innovation performance dimensions. In order to fill in this gap, this research applies the proposed dimensions in the case of Brazilian fashion companies, showing their validity in empirical studies.

As far as the limitations of this research go, it is worth mentioning the reduced volume of GRI reports available in the fashion industry. It is also important to highlight that only four companies make their data available (Cia Hering, Lojas Renner, Dudalina and Malwee). Other companies could benefit from the results of their sustainable actions, especially eco-innovations, based on the adoption of initiatives and their dissemination in the GRIs. 
From this study, practical questions emerge that can contribute to managers and companies in the Brazilian fashion industry. Initially, the focus on eco-innovations is predominantly related to the technological component, emphasizing processes. In this sense, business actions seek to resolve the accusations customarily attributed to the industry, such as cotton production, which employs large amounts of pesticides and water, even though the industry is accused of not taking enough responsibility toward sustainability (Thorisdottir \& Johannsdottir, 2019). Such a positive attitude indicates the change resulting from pressure and the need for the market to meet society's demands for more sustainable production technologies with less environmental impact.

As a suggestion for future studies, it is possible to point out the opportunity to investigate in greater depth the drivers of choices made by companies in the practices shown in the GRIs. In addition, studies could compare sustainable innovation practices in different countries, verifying local characteristics. In this sense, it is suggested to research organizations' motivations for adopting one or the other dimension of eco-innovation. Finally, a quantitative application of the theoretical model could also be carried out in future studies, contributing to the consolidation of the analyzed dimensions.

\section{References}

Arranz, N., Arroyabe, M. F., Molina-García, A., \& de Arroyabe, J. F. (2019). Incentives and inhibiting factors of eco-innovation in the Spanish firms. Journal of Cleaner Production, 220, 167-176.

Bardin, L. (2016). Análise de Conteúdo (2a ed.). Edições 70 LDA/Almedina Brasil.

Belkhir, L., \& Elmeligi, A. (2018). Assessing ICT global emissions footprint: Trends to 2040 \& recommendations. Journal of Cleaner Production, 177, 448-463.

Berelson, B. (1952). Content analysis in communication research. New York: The Free Press.

Borini, F. M., MacLennan, M. L. F., Pereira, R. M., Pavan, K. R., \& Hourneaux, F. Jr (2018). Green and social certifications make up for home market underdeveloped institutional environment? Evidences from Brazilian subsidiaries. Transnational Corporations Review, 10(4), 356-366. doi: 10.1080/19186444.2018.1556518.

Bossle, M. B., Dutra de Barcellos, M., Vieira, L. M., \& Sauvée, L. (2016). The drivers for adoption of ecoinnovation. Journal of Cleaner Production, 113, 861-872. doi: 10.1016/j.jclepro.2015.11.033.

Chen, J., Yin, X., \& Mei, L. (2018). Holistic innovation: An emerging innovation paradigm. International Journal of Innovation Studies, 2(1), 1-13.

Chen, L., Tang, O., \& Feldmann, A. (2015). Applying GRI reports for the investigation of environmental management practices and company performance in Sweden, China and India. Journal of Cleaner Production, 98, 36-46. doi: 10.1016/j.jclepro.2014.02.001.

Chesbrough, H. (2010). Business model innovation: Opportunities and barriers. Long Range Planning, 43(2-3), 354-363.

Choi, D., \& Han, T.-I. (2019). Green practices among fashion manufacturers: Relationship with cultural innovativeness and perceived benefits. Social Sciences, 8(5), 138.

Dangelico, R. M., \& Pontrandolfo, P. (2015). Being "green and competitive": The impact of environmental actions and collaborations on firm performance. Business Strategy and the Environment, 24(6), 413-430.

De Marchi, V. (2012). Environmental innovation and R\&D cooperation: Empirical evidence from Spanish manufacturing firms. Research Policy, 41(3), 614-623.

De Morais, A. S. A., Hoeckesfeld, L., Sarquis, A. B., \& Mussi, C. C. J. R. (2019). Omnichannel as strategy of innovation in youth fashion retail industry in Brazil. REMark, 18(2), 268.

Diaz-Garcia, C., Gonzalez-Moreno, A., \& Saez-Martinez, F. J. (2015). Eco-innovation: Insights from a literature review. Innovation-Management Policy and Practice, 17(1), 6-23. doi: 10.1080/ 14479338.2015.1011060. 
INMR

20,1

Doran, J., \& Ryan, G. (2016). The importance of the diverse drivers and types of environmental innovation for firm performance. Business Strategy and the Environment, 25(2), 102-119.

Figueiredo, P. N. (2009). Gestão da inovação: conceitos, métricas e experiências de empresas no Brasil. Livros Técnicos e Científicos.

Fundação Ellen MacArthur (2017). A new textiles economy: Redesigning fashion's future. Available from: https://www.ellenmacarthurfoundation.org/assets/downloads/publications/A-NewTextilesEconomy_Full-Report.pdf.

García-Granero, E. M., Piedra-Muñoz, L., \& Galdeano-Gómez, E. (2018). Eco-innovation measurement: A review of firm performance indicators. Journal of Cleaner Production, 191, 304-317.

Grose, L. (2019). Keynote-fashion and sustainability: Where we are and where we need to Be. Journal of Fashion Practice, 11(3), 291-301.

Hedberg, C. J., \& Von Malmborg, F. (2003). The global reporting initiative and corporate sustainability reporting in Swedish companies. Corporate Social Responsibility Environmental Management, 10(3), 153-164. doi: 10.1002/csr.38.

Horbach, J., Oltra, V., \& Belin, J. (2013). Determinants and specificities of eco-innovations compared to other innovations - An econometric analysis for the French and German industry based on the community innovation survey. Industry Innovation, 20(6), 523-543.

Hroncova, V., Jadudová, J., Hronec, M., \& Rolíková, S. (2017). Developing eco-innovation in business practice in Slovakia. Journal of Business Economics Management, 18(5), 1042-1061.

Hsu, C. C., Tan, K. C., \& Zailani, S. H. M. (2016). Strategic orientations, sustainable supply chain initiatives, and reverse logistics empirical evidence from an emerging market. International Journal of Operations and Production Management, 36(1), 86-110. doi: 10.1108/ijopm-062014-0252.

Kemp, R., \& Pearson, P. (2007). Final report MEI project about measuring eco-innovation (p. 10). Maastricht: UM Merit

Kozlowski, A., Searcy, C., \& Bardecki, M. (2015). Corporate sustainability reporting in the apparel industry: An analysis of indicators disclosed. International Journal of Productivity and Performance Management, 64(3), 377-397.

Kripka, R. M. L., Scheller, M., \& Bonotto, D. D. L. (2015). Pesquisa documental na pesquisa qualitativa: conceitos e caracterização. Revista de Investigaciones UNAD, 14(2), 55-73.

Kury, B., da Rocha, A., \& da Silva, J. F. (2019). Internationalization and the tale of the Cabo Frio beachwear cluster. In Contemporary Influences on International Business in Latin America (pp. 125-153). Cham: Palgrave Macmillan.

MacLennan, M. L. F., Suter, M. B., \& Spers, R. (2017). Challenges to the internationalisation of the Brazilian fashion industry. International Journal of Export Marketing, 1(4), 377-395.

Mascena, K. M. C. D., Fischmann, A. A., \& Boaventura, J. M. G. (2018). Priorização de stakeholders em empresas que divulgam relatórios GRI no Brasil. Brazilian Business Review, 15(1), 17-32.

McKinsey Global Fashion Index (2019, 2 de maio de). Mckinsey.com. Available from: https://www. mckinsey.com/industries/retail/our-insights/the-state-of-fashion.

Miles, M. B., \& Huberman, A. M. (1994). Qualitative data analysis: An expanded sourcebook. Sage.

NVivo11 (2016). Manual NVivo11. Acesso em 27 de março de 2021. Disponível em. Available from: .https://aprender.ead.unb.br/pluginfile.php/345106/mod_resource/content/0/NVivo11-GettingStarted-Guide-Plus-edition-Portuguese.pdf.

Organization for Economic Co-Operation and Development (OECD) (2005). The measurement of scientific activities: Proposed guideline for collecting and interpreting technological innovation data. Oslo Manual. Available from: www.oecd.org/dataoecd/35/61/2367580.pdf.

Oliva, F. L., Semensato, B. I., Prioste, D. B., Winandy, E. J. L., Bution, J. L., Couto, M. H. G., \& Santos, R. F. (2019). Innovation in the main Brazilian business industries: Characteristics, types and comparison of innovation. Journal of Knowledge Management, 23(1), 135-175. 
Orazalin, N., \& Mahmood, M. (2020). Determinants of GRI-based sustainability reporting: evidence from an emerging economy. Journal of Accounting in Emerging Economies, 10(1), 140-164. doi: 10.1108/JAEE-12-2018-0137.

Porter, M. E., \& Van der Linde, C. (1995). Toward a new conception of the environment-competitiveness relationship. Journal of Economic Perspectives, 9(4), 97-118. doi: 10.1257/jep.9.4.97.

Sá-Silva, J. R., Almeida, C. D. D., \& Guindani, J. F. (2009). Pesquisa documental: Pistas teóricas e metodológicas. Revista Brasileira de História \& Ciências Sociais, 1(1), 1-15.

Schumpeter, J. A. (1942). Capitalism, socialism and democracy. New York.

Shrivastava, P. (1995). The role of corporations in achieving ecological sustainability. Academy of Management Review, 20(4), 936-960.

Silva, L. A., Vicente, D. P., \& Galina, S. V. R. (2013). Criação e desenvolvimento de produtos em empresas brasileiras internacionalizadas: um estudo comparativo no setor de moda. Revista de Negócios, 18(3), 21-36.

Sutter, M. B., Galleli, B., MacLennan, M. L. F., Polo, E. F., \& Correa, H. L. (2015). Brazil's fashion and clothing industry: Sustainability, competitiveness and differentiation. Latin American Journal of Management for Sustainable Development, 2(3-4), 280-295.

Sutter, M. B., MacLennan, M. L. F., Polo, E. F., \& Strehlau, V. I. (2016). Diferenciação e competitividade da oferta de moda brasileira no mercado internacional. Revista de Administração Mackenzie, 17(1), 165-196.

Teece, D. (2010). Business models, business strategy and innovation. Long Range Planning, 43(2-3), 172-194.

Thorisdottir, T. S., \& Johannsdottir, L. (2019). Sustainability within fashion business models: A systematic literature review. Sustainability, 11(8), 2233.

Tidd, J., \& Hull, F. M. (2006). Managing service innovation: The need for selectivity rather than "best practice". New Technology, Work Employment, 21(2), 139-161.

Triguero, A., Moreno-Mondéjar, L., \& Davia, M. (2015). Eco-innovation by small and medium-sized firms in Europe: From end-of-pipe to cleaner technologies. Innovation, 17(1), 24-40.

Tumelero, C., Sbragia, R., \& Evans, S. (2019). Cooperation in R\&D and eco-innovations: The role in companies' socioeconomic performance. Journal of Cleaner Production, 207, 1138-1149.

Utterback, J. M., \& Abernathy, W. (1975). A dynamic model of process and product innovation. Omega, 3(6), 639-656.

Weerawardena, J., \& Mavondo, F. T. (2011). Capabilities, innovation and competitive advantage. Industrial Marketing Management, 40(8), 1220-1223.

\section{Further reading}

Pedersen, E. R. G., Gwozdz, W., \& Hvass, K. K. (2016). Exploring the relationship between business model innovation, corporate sustainability, and organisational values within the fashion industry. Journal of Business Ethics, 149(2), 267-284.

Tung, T., Koenig, H., \& Chen, H.-L. (2017). Effects of green self-identity and cognitive and affective involvement on patronage intention in eco-friendly apparel consumption: A gender comparison. Sustainability, 9(11), 1977.

\section{Corresponding author}

Maria Laura Ferranty Mac Lennan can be contacted at: ferranty@hotmail.com

For instructions on how to order reprints of this article, please visit our website:

www.emeraldgrouppublishing.com/licensing/reprints.htm

Or contact us for further details: permissions@emeraldinsight.com 